\title{
Respiration of bivalves from three different deep-sea areas: cold seeps, hydrothermal vents and organic carbon-rich sediments
}

\author{
Khripounoff Alexis ${ }^{1,{ }^{*}}$, Caprais Jean-Claude ${ }^{1}$, Decker Carole ${ }^{1}$, Le Bruhec $\mathrm{J}^{1}$, Noel Philippe ${ }^{1}$ \\ Husson Berengere ${ }^{1}$ \\ ${ }^{1}$ IFREMER/ Centre de Brest, Département REM/EEP/LEP, CS 10070, 29280 Plouzané-France \\ * Corresponding author : Alexis Khripounoff, email address : alexis.khripounoff@ifremer.fr
}

\begin{abstract}
:
We studied bivalves (vesicomyids and mytilids) inhabiting four different areas of high sulfide and methane production: 1) in the Gulf of Guinea, two pockmarks (650 m and $3150 \mathrm{~m}$ depth) and one site rich in organic sediments in the deepest zone (4950 m average depth), 2) at the Azores Triple Junction on the Mid-Atlantic Ridge, one hydrothermal site (Lucky Strike vent field, $1700 \mathrm{~m}$ depth). Two types of Calmar benthic chambers were deployed, either directly set into the sediment (standard Calmar chamber) or fitted with a tank to isolate organisms from the sediment (modified Calmar chamber), to assess gas and solute exchanges in relation to bivalve bed metabolism. Fluxes of oxygen, total carbon dioxide, ammonium and methane were measured. At the site with organic-rich sediments, oxygen consumption by clams measured in situ with the standard benthic chamber was variable (1.3-6.7 mmol $m-2 h-1)$ as was total carbon dioxide production (1-9.6 mmol m-2 h-1). The observed gas and solute fluxes were attributed primarily to bivalve respiration (vesicomyids or mytilids), but microbial and geochemical processes in the sediment may be also responsible for some of variations in the deepest stations. The respiration rate of isolated vesicomyids (16.1-.25.7 $\mu \mathrm{mol} g-1$ dry weight $\mathrm{h}-1)$ was always lower than that of mytilids $(33 \mu \mathrm{mol} g-1$ dry weight $h-1)$. This difference was attributed to the presence of a commensal scaleworm in the mytilids. The respiratory coefficient $(Q R) \geq 1$ indicated high levels of anaerobic metabolism. The O:N index ranged from 5 to 25 , confirming that vesicomyids and mytilids, living in symbiosis with bacteria, have a protein-based food diet.
\end{abstract}

Keywords : Deep-sea ; Benthic chamber ; Vesicomyid and Mytilid bivalves ; Respiration rate ; Cold seep ; Hydrothermal vent 


\section{Introduction}

In hydrothermal sites, cold seeps or areas rich in organic carbon, high fluxes of methane and sulfide support chemoautotrophic free-living and symbiotic bacteria. These fluxes provide the basis for complex microbial and metazoan communities. Many biological studies in these particular habitats have focused on the distribution, structure, nutrition, and food web architecture of faunal communities as well as on their interaction with the geochemistry of their environment. However, the metabolism of these organisms is poorly documented.

Bivalves are one of the most abundant chemosynthetic organisms inhabiting deep-sea reducing ecosystems with production of methane and sulfur (Lutz and Kennish, 1993; Sibuet and Olu, 1998; Fiala-Médioni et al., 2002; Duperon et al., 2005; Cosel and Olu; 2009). Vesicomyids and mytilids at these sites feed via symbiotic sulfide-oxidizing bacteria that inhabit bacteriocytes in their gills (Fiala-Médioni and Le Pennec, 1987). The vesicomyids provides its symbionts with sulfides taken up by its foot buried in the sulfide-rich sediments and mytilids directly uptaken via gill-associated symbionts. Oxygen and carbon dioxide are absorbed from the seawater that flows through the bivalve siphons above the sediment (Arp and Childress, 1983; Childress et al, 1984; Roeselers and Newton, 2012).

To study the necessary physiological requirements for deep-sea bivalve life, oxygen consumption and carbon and nitrogen excretion rates represent the gains and losses of energy associated with metabolism. The physiological responses of vesicomyids or mytilids to changes in the environment are extremely variable (Widdows et al., 1984; Tedengren et al., 1990; Navarro and Gonzalez, 1998). Bivalve-bacterial associations can thrive in sulfide-rich environments, surviving on the oxidation of sulfide. Bivalves uptake both sulfide and oxygen which do not normally exist together in water column due to rapid oxidation of sulfide. They are assumed to be involved in numerous interactions with the surrounding environment and organisms due to their size and abundance, (Olu et al, 2007; Marcon et al, 2014). 
64

Research directed at studying the unusual physiological adaptations of these animals is necessary to understand how these bivalves can live in such hostile environments, largely unhospitable to other animals. Studies on oxygen consumption rates have been performed using in situ measurements on hydrothermal vent mussels (Smith Jr., 1985) and other deepsea habitats maintained under in situ pressure conditions (Arp et al., 1984; Childress and Mickel, 1982, 1985; Henry et al, 2008). In these experiments, observed oxygen consumption rates are generally as high as those measured in shallow-water mussels.

The objective of our study was to estimate in situ the respiratory rate of vesicomyids and mytilids at four different deep-sea sites in the Gulf of Guinea and on the Mid-Atlantic Ridge. Measurements of oxygen, total dissolved inorganic carbon, methane and ammonium were obtained in situ using two different benthic chambers and were assessed along with vesicomyids or mytilids density and biomass. The results were examined according to the type of benthic chamber used, explored sites and bivalve species.

\section{Materials and Methods}

Study area

The study was carried out in three sites in the Gulf of Guinea explored during the WACS cruise (February 2011), the CongoLobe cruise (December 2011-January 2012) and in one site on the Mid-Atlantic Ridge in the Lucky Strike vent field during the Momarsat 2015 cruise (April 2015) on the R/V Pourquoi Pas?. All the deployments of Calmar were realized using the ROV Victor.

The first site in the Gulf of Guinea (Fig. 1) is an organic carbon-rich area on the distal lobe complex of the Congo deep-sea fan. This area is characterized by brown sediment with several "black pools" composed of a surface of reduced black sediment. This site likely receives large terrestrial organic inputs from the African continent, transported via the Congo 
89

90

91

92

submarine canyon system (Khripounoff et al., 2003; Vangriesheim et al, 2009). Four stations (A, B, F and C) were sampled in this area from 4750 to $5070 \mathrm{~m}$ depth (Figure 1). A distinctive ecosystem is associated with black pools and is characterized by a biological community that resembles those observed on pockmarks with microbial mats and vesicomyid bivalves (dominant species: Christineconcha regab and Abyssogena southwardae, Krylova et al. 2010). The three organic-rich stations (Fig. 1) were located in the main deposition zone of the Congo canyon along the track of the micro-channel that funnels the turbidity material to the terminal lobes except Station E, which was out of the turbidity input and was chosen as a deep-sea reference station.

The second site (Fig. 1), called Regab, is a giant pockmark $800 \mathrm{~m}$ in diameter at $3150 \mathrm{~m}$ depth, along the Congo margin (Olu-Le Roy et al. 2007). It is characterized by high habitat heterogeneity, with assemblages of the three major symbiont-bearing taxa encountered at cold-seeps: Vesicomyid bivalves (dominant species: C. regab), Mytilid bivalves (Bathymodiolus aff. boomerang) and Siboglinid polychaetes (Escarpia southwardae), as well as microbial mats.

The third site, called Guiness (Fig. 1), includes several small, less active pockmarks, from 580 to $690 \mathrm{~m}$ depth. The major benthic taxon observed was vesicomyids (Calyptogena valdiviae, and Elenaconcha guiness, Cosel \& Olu 2009). This pockmark is characterized by patchy vesicomyid beds associated with microbial mats.

The fourth site was the hydrothermal Lucky Strike vent field ( $1700 \mathrm{~m}$ average depth) at the Azores Triple Junction (ATJ) on the Mid-Atlantic Ridge. This area consists of a large central lava lake surrounded by three volcanic cones with several translucent smokers. Mytilid bivalves Bathymodiolus azoricus are the dominant megafaunal species and are distributed in patches of thousands of individuals (Desbruyères et al., 2001). 


\section{Calmar benthic chambers}

To assess the in situ metabolism community of bivalves, the Calmar benthic chamber (Caprais et al, 2010) was deployed by the ROV Victor 6000. Basically, Calmar is a $41 \mathrm{~cm}$ diameter cylinder that is open at one end. The Calmar unit weighs $14 \mathrm{~kg}$ in water and it is equipped with six $100 \mathrm{ml}$ sampling cells, an oxygen probe (Aadi, Norway) and a stirrer to homogenize the water in the chamber. The position of the sampling cells under the Calmar chamber and their closure mechanism preclude any suction and infiltration of uncontrolled water movement in the sealed Calmar chamber (Caprais et al. 2010). During the standard Calmar experiments (Fig. 2a), the incubation of bivalves directly on the sediment lasted for about $3 \mathrm{~h}$. At each station, a ring of $50 \mathrm{~cm}$ in diameter was deployed to guide the Calmar positioning. The standard Calmar measured exchanges between water and bivalves lodged in the sediment was deployed two times during the WACS cruise on mytilid beds and three times during the CongoLobe cruise on vesicomyid beds. Two standard Calmars were also used to measure flux exchanges on sediment without bivalves and represent background references in this study. Measurements on undisturbed B. azoricus beds with standard Calmar were not possible because the chimney walls do not allow such measurements.

The respiration rate of isolated bivalves was measured in situ using a modified Calmar chamber fitted with a specific tank (Fig. 2b) (Khripounoff et al.; 2014). It was deployed by the ROV at all four sites: Lobe, Regab, Guiness and Lucky Strike (Table 1). At the beginning of the experiment, bivalve shells were sampled on the bottom by the ROV with a net or with the ROV arm and dropped into the cylindrical tank. Then, after about $1 \mathrm{~h}$ of stabilization, the Calmar unit was placed over this tank, immersing the bivalves in exactly 311 of bottom water (Fig. 2b). The incubation then started and lasted for $3 \mathrm{~h}$ in situ on the bottom, close to the sampling area. The modified Calmar chamber fitted with a tank was used to incubate 7 shells of C. regab at the Lobe station, 17 shells of C. regab at the Regab station, 21 shells of $E$. 
guiness at the Guiness station and 24, 19 and 170 shells of B. azoricus at the Lucky Strike vent field.

Size, weight, density, biomass and elemental composition of vesicomyids and mytilids After each experiment with the benthic chamber (standard or modified Calmar), the sampled bivalves were identified, washed and frozen (samples incubated with the modified Calmar) or fixed in $4 \%$ buffered formalin (samples incubated with the standard Calmar). In the laboratory, shells were measured and dry weight ( $\mathrm{dw})$ of bivalves was determined after the body, excised from the shell, had been dried for 24 h at 60 C. B. azoricus mussels generally have a commensal polychaete, Branchipolynoe seepensis. The biomass of each species was measured separately in each shell. Total carbon and sulfur concentrations of dried total body were analyzed with a Leco CS 125 (USA) elemental analyzer.

The in situ bivalve density under the standard Calmar was estimated with two methods using photos and quantitative core samples (Decker et al., 2012). First, a ring of $50 \mathrm{~cm}$ diameter was deployed on a bivalve bed and photos of this circle were taken by the ROV to estimate bivalve density before benthic chamber deployment (Khripounoff et al., 2015). Then, after the recovery of Calmar at the end of incubation, a blade core $\left(0.036 \mathrm{~m}^{2}\right)$ was taken from within the ringed off area. Mean density was estimated from the average of these two measurements taken at each Calmar deployment. For each standard Calmar deployment, mean of biomass $\left(\mathrm{g} \mathrm{dw} \mathrm{m}^{-2}\right)$ were calculated using the mean density, estimated from photos and blade cores, and mean individual tissue dry weight calculated with the bivalves sampled with core. Only the living animals were taken into account to calculate de density and biomass of bivalves sampled with the blade corer. But it is not possible to discriminate dead and living animals in the photos. 


\section{Analytical methods and flux calculation}

Oxygen was measured in situ with an electrochemical sensor optode (Aadi). To calibrate the oxygen optode, oxygen concentration was also analyzed in triplicate aliquots on $10 \mathrm{~mL}$ water sampled in each cell using the modified Winkler titration method (Carrit et al. 1996). Total dissolved inorganic carbon (DIC) was determined using an infrared gas analyzer (Kaltin et al. 2005). Methane was analyzed by gas chromatography coupled with a head-space sampler (GC/HSS) (Sarradin and Caprais 1996) in $5 \mathrm{~mL}$ of water in $10 \mathrm{~mL}$ vials; precision was less than $4 \%$. Each chemical analysis was done in triplicate for each sampling cell. Ammonium was analyzed using a manual fluorimetric technique (Holmes et al., 1999).

The fluxes were calculated for the standard Calmar from the slopes of the linear regressions of oxygen, ammonia, $\Sigma \mathrm{CO}_{2}$, concentrations:

Total flux $\left(\mu \mathrm{mol} \mathrm{m} \mathrm{m}^{-2} \mathrm{~h}^{-1}\right) \mathrm{S}(\mathrm{V} / \mathrm{A})$ where $\mathrm{S}$ is the slope of the linear regression of gas or solute analysis, $\mathrm{V}$ is the chamber volume and $\mathrm{A}$, the surface area of the chamber.

The respiratory coefficient (RQ) was calculated as $\Sigma \mathrm{CO}_{2} / \mathrm{O}_{2}$ and the O:N index was calculated according to their atomic equivalents.

Bivalve respiration rate using the modified Calmar (in $\mu \mathrm{mol} \mathrm{g}^{-1} \mathrm{~h}^{-1}$ ) was calculated using the following expression: $\mathrm{B}^{-1}\left[\mathrm{Vt}^{-1}\left(\mathrm{C}_{2}-\mathrm{C}_{1}\right)\right]$ where $\mathrm{B}$ is the bivalve dry weight $(\mathrm{g} \mathrm{dw}) ; \mathrm{C}_{1}$ and $\mathrm{C}_{2}$, gas or solute concentration in the Calmar with bivalves at time 1 and $2\left(\mu \mathrm{mol} \mathrm{L}{ }^{-1}\right)$; $\mathrm{V}$, the volume of water under the Calmar chamber (1); and t, the time interval between measurements (h).

For the numerical treatment of oxygen consumption and body size data, the relationship between whole animal oxygen consumption and body weight can be described by the following equation (1): oxygen consumption $=\mathrm{aW}^{\mathrm{b}}$ (Von Bertalanffy, 1957), where $\mathrm{W}$ is the body weight. The relationship between weight-specific oxygen consumption $\mathrm{R}$ and body weight can therefore be expressed as $\mathrm{R}=\mathrm{aW}^{\mathrm{b}-1}(2)$. Since the value of (b) in equation 1 
189

190

191

192

193

194

195

normally has a value of $<1$, the value of $(b-1)$ in equation 2 will have a negative value (Von Bertalanffy, 1957).

\section{Results}

\section{Bivalve characteristics}

During the incubation with the standard Calmar on the sediment, bivalves dominated the megafauna biomass at each experiment. A comparison of the two methods used to calculate the bivalve density (except for the mytilids at the Regab station where only photos were used) showed that the results obtained with the corer were higher by factor 2-3 of those obtained by counts based on the photos (Table 2). At the Lobe and Regab sites, colonized by C. regab, vesicomyid biomass ranged from 157 to $1066 \mathrm{~g} \mathrm{dw} \mathrm{m}^{-2}$. The biomass of mytilids at Regab was low $\left(75-90 \mathrm{~g} \mathrm{dw} \mathrm{m}^{-2}\right)$.

The bivalve characteristics in the incubation experiments with the standard Calmar and the modified Calmar-tank are summarized in Fig 3. With the standard Calmar at Lobe, we observed a minor difference in C. regab weight between Lobe B and Lobe A. The mytilid $B$. boomerang at Regab was the bigger (mean=150 $\pm 15.4 \mathrm{~mm}$ ) of the bivalve species used in this experiment. With the modified Calmar-tank at Regab, individual main length and dry weight of C. regab was higher than that observed at Lobe, by a factor of two: respectively $91.2 \pm 7.7$ and $54.9 \pm 5.9 \mathrm{~mm}$ for length and $4.52 \pm 0.9$ and $1.47 \pm 0.4 \mathrm{~g} \mathrm{dw}$ for mass. The size of E. guiness shells at Guinness was more similar to that of C. regab at Lobe (54.2 $\pm 5.9 \mathrm{~mm})$ (Fig. 3). The mussels at the Lucky Strike hydrothermal vent were the smallest bivalves used in this study with individual length ranging from 12 to $72 \mathrm{~mm}$ and dry weight mass ranging from 0.005 to $2.2 \mathrm{~g} \mathrm{dw}$. B. azoricus features the presence of a commensal scaleworm, B. seepensis, in almost all living shells. The weight of the polychaete varied from 0.001 to $0.15 \mathrm{~g} \mathrm{dw}$ and represented about $10 \%$ of the mussel weight in each shell. 
214 The elemental composition (Table 3) of two vesicomyid species and the two mytilid species

215 showed similar concentrations of carbon (38.5 to 45.6\%). However, we observed a large

216 difference in tissue sulfur concentration between E. guiness (5.1\%) and C. regab (12.7 to

$21717.2 \%)$ and between C. regab (Lobe= $12.7 \%)$ and C. regab (Regab = 16.0), (Kruskal-Wallis

218 test, $\mathrm{p}<0.01$ and non-parametric multiple test). B. boomerang and B. azoricus mytilids were

219 characterized by a very low concentration of sulfur (1.2-1.5\%) (Table 3).

In situ exchanges of gases and solutes at the water-sediment interface under the standard

\section{Calmar chamber}

The total oxygen uptake (TOU), measured with the standard Calmar on vesicomyids or mytilids lodged on sediment, was between 1.29 and $6.71 \mathrm{mmol} \mathrm{O}_{2} \mathrm{~m}^{-2} \mathrm{~h}^{-1}$ (Table 4). The minimum $\mathrm{O}_{2}$ consumption was observed in the mytilid population and the maximum at the

Lobe A station. The two TOU references measured close to the vesicomyid bed at Lobe A and

$\mathrm{C}$ show a low sediment metabolism of 0.3-0.4 $\mathrm{mmol} \mathrm{O}_{2} \mathrm{~m}^{-2} \mathrm{~h}^{-1}$. The flux of $\Sigma \mathrm{CO}_{2}$ ranged from 1.0 (Regab) to 9.6 (Lobe A) $\mathrm{mmol} \mathrm{CO}_{2} \mathrm{~m}^{-2} \mathrm{~h}^{-1}$. During incubation, $\mathrm{NH}_{4}{ }^{+}$concentration increased significantly, indicating measurable ammonium production by organisms living in the sediment. The production rate observed under the Calmar chamber ranged from 0.1 (Regab) to 0.24 (Lobe A) $\mathrm{mmol} \mathrm{NH}_{4}{ }^{+} \mathrm{m}^{-2} \mathrm{~h}^{-1}$. $\mathrm{CH}_{4}$ diffusion was always detected at the Regab and Lobe sites with the standard Calmar, varying from 0.35 (Lobe B) to $4.5 \mathrm{mmol} \mathrm{m}{ }^{-2}$ significant sulfide flux was detected under any Calmar chamber; the detection level of our analytical method was $>20 \mathrm{mmol} / \mathrm{L}$. All these results are summarized in Table 4 . 
We first assumed that the metabolism of bivalves (host and symbionts or commensals), in the experiments using the standard Calmar, was responsible for the main exchange at the interface water-sediment. Based on this hypothesis, the bivalve respiration rate was calculated in terms of bivalve dry weight (Table 5) on the estimated biomass under each Calmar chamber (Table 2). Across the different stations, vesicomyid oxygen consumption varied from $6.2 \mu \mathrm{mol} \mathrm{O} \mathrm{g}^{-1} \mathrm{dw} \mathrm{h}^{-1}$ (Lobe A and F) to $11.2 \mu \mathrm{mol} \mathrm{O}_{2} \mathrm{~g}^{-1} \mathrm{dw} \mathrm{h}^{-1}$ (Lobe B). Mussel oxygen respiration rate was about $16 \mu \mathrm{mol} \mathrm{O}_{2} \mathrm{~g}^{-1} \mathrm{dw} \mathrm{h} \mathrm{h}^{-1}$ (Table 5). Assuming that bivalves produced the majority of $\Sigma \mathrm{CO}_{2}$, mean production was about $10 \mu \mathrm{mol} \mathrm{CO} \mathrm{CO}^{-1} \mathrm{dw} \mathrm{h}^{-1}$ and the RQ ranged from 0.8 to 1.5 . During incubation, the bivalve excretion was certainly the main factor contributing to the ammonium production and it was about $0.56 \mu \mathrm{mol} \mathrm{NH}_{4}^{+} \mathrm{g}^{-1} \mathrm{dw} \mathrm{h}^{-1}$. The maximum ammonium rate was observed in the mussel bed $\left(0.83 \mu \mathrm{mol} \mathrm{NH}_{4}^{+} \mathrm{g}^{-1} \mathrm{dw} \mathrm{h}^{-1}\right)$ (Table 5). The mean O:N ratio obtained with vesicomyids was $7.4 \pm 4.6$ and 24.4 with mytilids.

Under the modified Calmar-tank, only the respiration rate of isolated bivalves and their symbionts was measured, i.e. without the interaction of any other organism or any chemical exchanges from the sediment. For vesicomyids, the E. guiness respiration rate in the shallower Guiness station was greater $\left(25.7 \mu \mathrm{mol} \mathrm{O} \mathrm{g}^{-1} \mathrm{dw} \mathrm{h} \mathrm{h}^{-1}\right)$ than that of C. regab sampled at Regab or Lobe (about $17 \mu \mathrm{mol} \mathrm{O}_{2} \mathrm{~g}^{-1} \mathrm{dw} \mathrm{h} \mathrm{h}^{-1}$ ). The oxygen consumption rate of $C$. regab varied very little between the Regab and Lobe stations. However, the biomass and the mean size of individuals used in the modified Calmar-tank were higher at Regab than at Lobe (Fig. 3). The mytilids at the hydrothermal vent smaller than $0.3 \mathrm{~cm}$ in length had the highest respiration rate observed in this study $\left(33.6 \mu \mathrm{mol} \mathrm{O} \mathrm{O}^{-1} \mathrm{dw} \mathrm{h} \mathrm{h}^{-1}\right)$. The respiration of larger $B$. azoricus was lower (about $20 \mu \mathrm{mol} \mathrm{O}_{2} \mathrm{~g}^{-1} \mathrm{dw} \mathrm{h}^{-1}$ ) and it was comparable to the respiration of similarly sized vesicomyids. The bivalve $\Sigma \mathrm{CO}_{2}$ production ranged from 16 (Regab) to 28 (Guiness) $\mu \mathrm{mol} \mathrm{CO} \mathrm{Cg}^{-1} \mathrm{dw} \mathrm{h}^{-1}$ and the RQ was close to 1 . During incubation, $\mathrm{NH}_{4}^{+}$ 
264

265

266

267

268

269

270

271

272

273

274

275

276

277

278

279

280

281

282

283

284

285

286

287

288

concentration always increased during the experiment with the modified Calmar-tank. The measured excretion rate ranged from 0.3 (B. azoricus) to 1.25 (C. regab) $\mu \mathrm{mol} \mathrm{NH}_{4}{ }^{-} \mathrm{g}^{-1} \mathrm{dw} \mathrm{h}^{-}$ 1 . The O:N ratio was clearly lower than under the standard Calmar with vesicomyids.

\section{Relationship between oxygen consumption and body weight}

In the present study, it was only possible to determine the relationship between oxygen consumption and body weight for small bivalves between 0.03 to $4 \mathrm{~g}$ dw. Only clams from Regab exceeded $2 \mathrm{~g} \mathrm{dw}$. The relationship between oxygen consumption and body weight of bivalves obtained during the present study is

$\mathrm{R}=21.3 \mathrm{~W}^{-0.16}$ for vesicomyids and $\mathrm{R}=21.2 \mathrm{~W}^{-0.19}$ for mytilids (Fig. 4).

\section{Discussion}

General features of bivalves

Bivalves (vesicomyids and mytilids) are widespread in chemosynthetic ecosystems, and occur at most known cold-seep sites (Krylova and Sahling, 2010) and hydrothermal vents

(Desbruyères et al., 2001). Our results show variation in density and mean individual biomass in the Gulf of Guinea and in the ATJ. The hydrothermal mytilids at the Lucky Strike site were small and the distribution around the chimney was patchy. In the Gulf of Guinea, we observed some patterns in vesicomyids sampled from different areas (Fig. 3). The large majority of $C$. regab specimens were particularly small at all Lobe sites compared with the same species at Regab sites. This difference suggests that vesicomyid population at Lobe consisted mostly of young or dwarf individuals. However, the presence of only one or two cohorts at Lobe (personal data) suggests a young population or the stunted growth hypothesis. The elemental composition of vesicomyid tissues was characterized by high differences in sulfur concentrations between E. guiness and C. regab (Table 3). The symbionts of vesicomyid clam 
tend to accumulate elemental sulfur while the mussel symbionts do not. These differences may be due to interspecific variation in sulfide physiology, e.g. divergent patterns in sulfide exploitation and storage, as previously observed in both species in Monterey Bay (Goffredi and Barry 2002). Elemental sulfur is known to be an energy storage product for sulfideoxidizing symbiotic bacteria (Vetter, 1985). These reserves provide fuel for symbiotic bacteria metabolism, even in the absence of a sulfide supply (Vetter et al. 1985, Fisher et al. 1988, Fiala-Médioni and Lepennec, 1989, Goffredi and Barry, 2002). The higher sulfur storage capacity in $C$ regab is also a mechanism that can facilitate the adaptation to the fluctuations in sulfide fluxes that occur in these habitats.

\section{Effects of bivalves on transfers at the water-sediment interface}

The role of vesicomyids or mytilids in gas exchanges at the water-sediment interface has not been studied as well as their distribution in cold seeps. However, they were the main contributor to benthic respiration at the different stations studied in the Gulf of Guinea. Our values of TOU varied from 1.3 to $6.7 \mathrm{mmol} \mathrm{O}_{2} \mathrm{~m}^{-2} \mathrm{~h}^{-1}$ and similar measurements have been previously obtained at these cold-seep sites. For example, in situ TOU measured at the Regab cold-seep on clam beds varies between 2.1 and $24.6 \mathrm{mmol} \mathrm{O}_{2} \mathrm{~m}^{-2} \mathrm{~h}^{-1}$ (Pop Ristova et al., 2012), 13.8 and $20.5 \mathrm{mmol} \mathrm{O}_{2} \mathrm{~m}^{-2} \mathrm{~h}^{-1}$ (Decker et al., 2012) and 11.3 and $18.0 \mathrm{mmol} \mathrm{O}_{2} \mathrm{~m}^{-2} \mathrm{~h}^{-1}$ (Khripounoff et al., 2015). TOU rates ranging from 1.3 to $6.7 \mathrm{mmol} \mathrm{O}_{2} \mathrm{~m}^{-2} \mathrm{~h}^{-1}$ have been measured in different habitats outside of the Gulf of Guinea, on the Napoli mud volcano in Mediterranean sea (Caprais et al., 2010), on the Hakon Mosby mud volcano (Felden et al., 2010) and at the Hikurangi margin (Sommer et al., 2010). $\Sigma \mathrm{CO}_{2}$ fluxes, ranging from 1 to 9.6 mmol $\mathrm{m}^{-2} \mathrm{~h}^{-1}$, are not only produced by clams, mussels and metazoan respiration, but also by the oxidation of methane by archea (Boetius et al., 2013). Bacterial activity is responsible also for the degradation of organic matter. Conversely, $\mathrm{CO}_{2}$ can be consumed by methanogenic 
314 bacteria (Whiticar, 1999). The consequence of the -time-lag between oxygen consumption

315 and $\mathrm{CO}_{2}$ production is high variation in the RQ value. The RQ value is generally equal to 0.75

316 for various marine invertebrate species (Koopmans (2010), but it ranged from 0.8 to 1.2 in

317 this study (Table 4). In this case, high RQ values may be due to an increase in anaerobic

318 mineralization of organic matter and anaerobic oxidation of methane (AeOM). The benthic

319 chamber, which accumulates carbon during incubation, can in situ artificially accelerate the

320 process of carbonate precipitation (Aloisi et al., 2002). Our RQ values were greater than those

321 obtained by Khripounoff et al. (2015) at the same stations (0.6). This discrepancy is not easily

322 explained.

323 The excretion of ammonium is due to protein breakdown and its flux measured under the

324 Calmar chamber can be attributed almost exclusively to vesicomyids, like $\mathrm{O}_{2}$ and $\Sigma \mathrm{CO}_{2}$

325 fluxes. The excretion of bivalves was on average to $0.17 \mathrm{mmol} \mathrm{NH} 4^{+} \mathrm{m}^{-2} \mathrm{~h}^{-1}$ and this value is

326 lower than the values $\left(0.37 \mathrm{mmol} \mathrm{NH} 4^{+} \mathrm{m}^{-2} \mathrm{~h}^{-1}\right)$ reported by Khripounoff et al. (2015).

327 Energy availability, in the form of methane, sulfide and oxygen fluxes, and the type of

328 seafloor substrate play a central role in the composition and distribution of cold-seep faunal

329 communities at local and regional spatial scales (Olu-Le Roy et al., 2007; Ritt et al., 2011;

330 Decker et al., 2012; Fischer et al., 2012).

331

332

Respiratory rate of bivalve beds on sediment

333 Our approach using the Calmar chamber depicts the metabolic function of vesicomyids or

334 mytilids based on their integrated response at rest without manipulation. The first assumption

335 is to consider that the observed oxygen consumption is essentially due to global clam or

336 mytilid respiration (i.e. host and symbionts). The respiratory rate of vesicomyids and mytilids

337 was estimated at 7.9 and $16 \mu \mathrm{mol} \mathrm{O}_{2} \mathrm{~g}^{-1} \mathrm{dw} \mathrm{h} \mathrm{h}^{-1}$, respectively (Table. 5). However, this

338 estimation requires the exact biomass of bivalves under the standard Calmar, leading to 
uncertainty in the estimated respiration values. Regardless of these limitations, our results show vesicomyid oxygen consumption rates that are roughly half those that were measured in Khripounoff et al. (2015) and Decker et al. (2012) using the same equipment at the same stations. But given the uncertainties in estimation of bivalve biomass, that is more or less within the expected error range. The proportion of oxygen, consumed by other reactions, such as the respiration of small benthic organisms (macrofauna, meiofauna, and microfauna), a variety of methanotrophic archea, nitrification or chemical oxidation was estimated using the Calmar reference deployed at Lobe A and C (Table 4). It was about $10 \%$ of the total TOU measured under standard Calmar with clams. But this value is given for information only because the heterogeneity of sediment at a scale of few $\mathrm{cm}$ does not ensure the good representation of selected areas as reference. Thus, the intensity of these oxygen consumptions in the sediment represents additional sources of uncertainty. The ratio between macrofauna and symbiotic bivalve biomass is low in cold seeps (Sahling et al. 2002; Decker et al., 2012) and therefore, macrofaunal metabolism is likely negligible for the estimation of respiration in this study. The contribution of AeOM and sulfide oxidation by bacteria to the total oxygen consumption is unknown and may vary with the intensity of fluid flow and related microbial and faunal colonization (Boetius and Wenzhofer, 2013). In our case, there was no bacterial mat under the standard Calmar with the clams and the thickness of the oxidized sediment was less than 1 $\mathrm{mm}$, thereby limiting the possibility of AeOM activity (Sommer et al., 2006). Bivalve communities were an oxygen sink, but not to an extent that would result in insufficient reoxidation and stimulation of methane, manganese and iron efflux compared with bare sediments. However, we cannot exclude the possibility that bivalve communities had increased respiration and bio-deposition and thus stimulated anaerobic processes (Zaiko et al. 2010). In this study, high $\mathrm{CO}_{2}$ rates with high $\mathrm{RQ}$ values (1.5) are due to anaerobic 
metabolism, which was greater than during the previous study at the same area (Khripounoff et al., 2015) and demonstrate the heterogeneity and the diversity of sediment at small scales. Atomic O:N ratios are related to the availability of energy stores and the utilization of body proteins (Shumway and Newell, 1984). This ratio produces an index of the relative amounts of protein, compared with carbohydrates and lipids that are catabolized by the organism. O:N ratios provide meaningful data on the metabolic state of an organism. When only protein is metabolized, the $\mathrm{O}: \mathrm{N}$ ratio is 7 (Ikeda et al. 2000). When O:N values are higher than 24 , lipids or carbohydrates are identified as the major components in the catabolism. O:N ratios can vary, rising or falling in response to body weight, type of diet, and starvation, depending on the biochemical composition of the organism (Mayzaud and Conover, 1988). In the present study, the O:N values ranged from 4.9 to 10.6 , indicating the dominance of protein catabolism (Ikeda, 1977). Vesicomyids indeed feed on the symbiotic bacteria production likely rich in proteins. However, these $\mathrm{O}: \mathrm{N}$ values cannot reflect fasting conditions because the duration of the experiment was not long enough to mobilize reserves and alter metabolism, as occurs when animals are exposed to starvation conditions.

\section{Respiration rate of isolated vesicomyids and mytilids}

The advantage of the Calmar-tank chamber is to eliminate disturbance provided by thesediment exchanges, to know the exact biomass of bivalves in the tank and to study the respiration of organisms living on hard substrates. However, the bivalves are transferred from their substrate to the benthic chamber tank and they are not in their original sulfur-rich water during the incubation period. This study shows that isolated C. regab and E. guiness have respiration rates equal to $17 \mu \mathrm{mol} \mathrm{O}_{2} \mathrm{~g}^{-1} \mathrm{dw} \mathrm{h}^{-1}$ and $26 \mu \mathrm{mol} \mathrm{O}_{2} \mathrm{~g}^{-1} \mathrm{dw} \mathrm{h}^{-1}$, respectively. $C$. regab was sampled between 3000 and $5000 \mathrm{~m}$ depth at a temperature ranging from 2.38 to $2.55^{\circ} \mathrm{C}$, whereas $E$. guiness lives at $600 \mathrm{~m}$ depth and a temperature of $7.1^{\circ} \mathrm{C}$. These species 
may have distinctive respiratory physiology that can explain the observed variation of respiratory rate. Nevertheless, the difference in size between the studied vesicomyids from 0.7 to $4.3 \mathrm{~g} \mathrm{dw}$ per individual is the main source of this difference. The figure 5 shows that the ratio respiration rate/ biomass between the two species plots on the same curve. In addition, the incubation experiment on B. azoricus of several sizes also showed respiration rates increasing from 19.6 to $33.6 \mu \mathrm{mol} \mathrm{g}^{-1} \mathrm{dw} \mathrm{h}^{-1}$, in a pattern inversely proportional to the size of the individuals (Table 5). The comparison between hydrothermal mytilids and vesicomyids living in cold seeps or organic-rich sediment does not show large difference. The power regression lines of vesicomyids and mussels at Figure 4 actually overlap perfectly. The presence of the commensal polychaete $B$. seepensis does not seem increase the individual respiratory rate knowing that the polychaete represents about $10 \%$ of the mussel weight. In the relationship between oxygen consumption and body weight, values of the weight exponent $\mathrm{b}-1$ in the equation $\mathrm{Ro}_{2}=\mathrm{aW}^{\mathrm{b}-1}$ show high interspecific variation within different invertebrate groups (Bayne and Newell, 1983). Among bivalves, there are not only interspecific differences in the value of the exponent b-1, but also intraspecific differences. Mytilus edulis shows typical values: for example -0.226 in winter and -0.298 in summer (Bayne et al., 1973), suggesting that the measured physiological differences, such as respiration, are largely determined by environmental rather than genotypic factors (Widdows et al., 1984). For the vesicomyids or mytilids in this study (Fig. 5), the difference of in the value of the $b-1$ exponent between vesicomyids and mytilids ( -0.16 and -0.19 respectively) was essentially due to differences in size rather than in the metabolism-to-respiration ratio (Taylor and Brand, 1975).

The comparison of vesicomyids or mytilids oxygen consumption rates measured in this study with those of the literature is complicated by the close relationship between food supply and metabolism and the lack of a standard approach. Therefore, comparisons can only be done 
413 between groups of animals that exhibit the same type of metabolism. Although many species

414 of deep-sea bivalves have been described, physiological measurements have been made on

415 very few species not only due to sampling difficulties, but also because deep-sea animals are

416 difficulty to study in situ or to maintain alive in the laboratory. Respiration rates have been

417 measured for a few deep-sea mussels (review by Mahaut et al., 1985; Smith Jr, 1985;

418 Jarnegren and Altin, 2006). For example, the ex situ experimentally obtained oxygen

419 consumption rate of the vent species Calyptogena magnifica (Boss and Turner, 1980) from

420 the Galapagos Rift ranges from $0.4 \mu \mathrm{mol} \mathrm{O}_{2} \mathrm{~g}^{-1}$ wet weight $\mathrm{h}^{-1}$ at $2.1^{\circ} \mathrm{C}$ to $1.58 \mu \mathrm{mol} . \mathrm{O}_{2} \mathrm{~g}^{-1}$

421 wet weight $\mathrm{h}^{-1}$ at $88^{\circ} \mathrm{C}$ (Arp et al., 1984). Assuming that the dry weight of clams is equal to

$42225 \%$ of the wet weight (personal data), the respiration rate of $C$. magnifica is 1.6 to $6.3 \mu \mathrm{mol}$

$423 \mathrm{O}_{2} \mathrm{~g}^{-1} \mathrm{dw} \mathrm{h}{ }^{-1}$. Conversely, large numbers of bivalves in shallow depths have been studied in

424 different ways within physically variable environments (see review in Bayne and Newell,

425 1983). Standard metabolism is represented by negligible feeding activity, and is considered to

426 be a resting state. In the present study, the standard rates of metabolism approached

427 maintenance rates. Deep-sea vesicomyids of the Gulf of Guinea and mytilids of ATJ are at the

428 upper extremes of respiration rate when comparing these values with the measurements made

429 on shallower mussels (Fig. 5) investigated at similar experimental temperatures (from 2.7 to

$43020 \mu \mathrm{mol} \mathrm{O}_{2} \mathrm{~g}^{-1} \mathrm{dw} \mathrm{h}^{-1}$, Jarnegren and Altin, 2006). The shallow suspension-feeding mussels

431 chosen from this selection were generally adults, measuring 20-50 cm in length (Vahl, 1973).

432 The compilation of all the existing data on the respiration rate of deep-sea benthic organisms,

433 measured at comparable ambient temperatures $\left(2-4^{\circ} \mathrm{C}\right)$, suggest an allometric relationship,

434 relating individual respiration rate to individual weight of about $10 \mu \mathrm{mol} \mathrm{O} \mathrm{g}^{-1} \mathrm{dw} \mathrm{h}^{-1}$

435 (Mahaut et al, 1985). Similarly, the respiration rate of the deep-sea hydrothermal mytilid

436 Bathymodiolus thermophilus is $10.3 \mu \mathrm{mol} \mathrm{O} \mathrm{g}^{-1} \mathrm{dw} \mathrm{h}^{-1}$ (Smith Jr, 1985) at $2500 \mathrm{~m}$ depth on

437 the Galapagos Rift for mussels with a mean dry weight of $10 \mathrm{~g}$. In comparison, B. azoricus 
$438 \quad\left(19.6-33.6 \mu \mathrm{mol} \mathrm{O} \mathrm{g}^{-1} \mathrm{dw} \mathrm{h}^{-1}\right)$ in our experiments were smaller with a mean size from 0.03 to

$439 \quad 0.7 \mathrm{~g} \mathrm{dw}$. This large difference in size explains the difference in respiration rate observed

440 between the two hydrothermal mytilid species which both harbor commensal polychaetes.

441 The water temperature differences between the Galapagos Rift $\left(1.8^{\circ} \mathrm{C}\right)$ and this study $\left(4.6^{\circ}\right.$

442 C) is also a factor that can explain the observed differences in respiration rate between these

443 two species.

444 Several factors, other than temperature and size, also affect the respiration rate of most

445 bivalves, including food availability, ecological situation, stress, species characteristics and

446 gametogenic stage. This list is not exhaustive. Smith Jr (1985) showed a significant difference

447 in the respiration rate between mytilids close to a vent and mytilids at several meters from this

448 vent due to the modification of the water environment. Furthermore, our experiments were

449 always based on a group of a dozen individuals in the benthic chamber and not a single

450 individual as generally described in the literature. The "group effect" on the respiration rate

451 has never been studied and may also affect the interpretation of our results. The production of

$452 \mathrm{CO}_{2}$ by the respiration of isolated bivalves (from 16 to $47 \mu \mathrm{mol} \mathrm{CO} \mathrm{g}^{-1} \mathrm{dw} \mathrm{h}^{-1}$ ) was higher

453 than that observed in animals living in the sediment. Consequently, RQ was always $>1$ and was

454 greater than this theoretical range of 0.75 (see above). When measuring $\mathrm{CO}_{2}$ production and

$455 \mathrm{O}_{2}$ consumption rates over less than $6 \mathrm{~h}$, the degree of coupling for these two gases is a

456 function of the differential storage capacity of the animal. The differential diffusion rates of

$457 \mathrm{CO}_{2}$ and $\mathrm{O}_{2}$ between the animal and the water, and the differential controls on $\mathrm{CO}_{2}$ production

458 and $\mathrm{O}_{2}$ consumption are often determined by the physiological characteristics of the species

459 (Hatcher, 1989). Symbionts, when fueled with reduced chemicals, also consume $\mathrm{CO}_{2}$. But, in

460 the Calmar-tank, without sulfur and methane, the activity of symbionts should be stopped

461 altogether. In the standard Calmar, symbionts from vesicomyids could rely on elemental

462 sulfur and continue to consume $\mathrm{CO}_{2}$ because the pathway is activated. The two types of 
463

464

experiments (standard versus tank) could therefore yield different RQ values. Ammonium excretion in mussels was lower than in vesicomyids (Table 5). As with the standard Calmar, the O:N ratio was $<10$ for vesicomyids that depend exclusively on symbionts for their nutrition, indicating the dominance of protein in catabolism (Ikeda, 1977). The food sources for mytilids in hydrothermal vents are more diverse, and include particles in the water environment as well as different symbiotic forms. The ratio $\mathrm{O}: \mathrm{N} \approx 24$ may be the result of increases in lipid and carbohydrate catabolism. However, the $\mathrm{O}: \mathrm{N}$ ratio can vary also in response to several factors such as starvation and the biochemical composition of the organism (Bayne et al., 1973). The low ratio may need another explanation. Several vesicomyid symbionts possess nitrate reductase genes (Newton et al., 2008), suggesting the production of $\mathrm{NH}_{4}^{+}$and hence a greater than expected proportion of ammonium excretion.

This could also explain the difference between the mussels and the vesicomyids in this study.

\section{Comparison of standard Calmar chamber and the modified Calmar-tank chamber}

The comparison of our data obtained with standard Calmar chamber and the modified Calmar-tank chamber during the same cruise shows that undisturbed clams have lower respiratory metabolism than clams isolated in the tank. One major limitation of the measurements is that the biomass is not estimated the same way. The biomass calculation under the Calmar-tank did not raise any question because all bivalves were sampled and dried. On the contrary, the biomass under the standard Calmar was only estimated by photographs or partial collections and the error in the calculation of the biomass can therefore be high. Stress from ROV handling at the beginning of the experiment appears to lead to oxygen consumption rates that can remain high for several hours, leading to an overestimation of basal rates. Deepsea species are possibly more sensitive to this handling disturbance. In our case, during the Calmar-tank experiments, bivalves were taken out of their natural environment without 
sulfide fluxes that supply energy to the bacterial symbionts. Reactions of the

bivalve/symbiotic associations to this new situation are unknown and changes in metabolism cannot be excluded. Oxygen consumed by vesicomyids measured in the Calmar-tank was about 1.5 to 3 times higher than those measured intact on sediment with the standard Calmar (Table 5). Is this difference only the consequence of the bivalve transfer into the tank? Interestingly, the measurements made by Decker et al. (2012) and Khripounoff et al. (2015) with the standard Calmar at the same stations (Table 4) showed results similar to our Calmartank values rather than to those obtained here with the standard Calmar (Table 5). In any case, handling affected deep-sea animal metabolism in all experiments, performed in situ or ex situ.

\section{Conclusion}

Advances in our understanding of processes underlying life in extreme deep-sea environments are very likely to contribute to a new model of the limits or main factors that regulate metazoan life. Closer study of the physiological ecology of these very different species has the potential to reveal, for example, the range of adaptations in clams and mussels and can serve as a model for other chemosynthetic taxa. The present study provides new insights based on intact, undisturbed sediments with bivalve communities and on isolated clams and mussels. We demonstrated that the presence of bivalves significantly affects benthic fluxes of $\mathrm{O}_{2}, \mathrm{CO}_{2}$ and $\mathrm{NH}_{4}{ }^{+}$in deep-sea sediments. However, these data have some limits because interactions occur between vesicomyids or mytilids, small benthic organisms and sediment. In isolated bivalves removed from sediments, allometric differences in bivalve size are the major explanation behind differences in respiration rate. At similar sizes, there were no differences between mussels and clams in terms of oxygen consumption. The $\mathrm{CO}_{2}$ production rate by deep clams was always higher than the predicted model indicating possible decoupling between oxidation and the storage capacity of the animal for carbon dioxide and oxygen 
513 gases. Ammonium excretion rate differs between mussels and clams, suggesting that only

514 protein was metabolized as an energy substrate in vesicomyids, but not in mytilids.

515

516 Acknowledgements

517 We are grateful to C. Rabouille and P. M. Sarradin, chief scientists of the Congolobe and

518 Momarsat 2015 cruises, respectively. We thank also the scientific and technical staff who

519 participated in these cruises. We acknowledge the captains and the crews of the R/V Pourquoi

520 Pas? and the ROV Victor teams. The Congolobe project is supported by the French National

521 Research Agency project ANR 11 BS56 030 02: Transfer of organic carbon and ecosystem

522 functioning in the terminal lobes of the submarine Congo. The Momarsat project is supported

523 by the Laboratory of Excellence LabexMER (ANR-10-LABX-19) and EMSO European

524 Community's Seventh Framework Programme (FP7/2007-2013) under grant agreement no.

525211816.

526 
527

528

529

530

531

532

533

534

535

536

537

538

539

540

541

542

543

544

545

546

547

548

549

550

\section{References}

Aloisi , G., Bouloubassi, I., Heijs, S.K., Pancost, R.D., Pierre, C., Sinninghe Damste, J.S., Gottschal, J.C., Forney, L.J., Rouchy, J.-M., 2002. CH4-consuming microorganisms and the formation of carbonate crusts at cold seeps. Earth Planet. Sci. Lett. 203, 195-203.

Arp, A.J., Childress, J.J., 1983. Sulfide binding by the blood of the hydrothermal vent tube worm Riftia pachyptila .Science 4582, 295-297.

Arp, A.J., Childress, J.J., Fisher C.R., 1984.Metabolic and blood gas transport characteristics of the hydrothermal vent bivalve Calyptogena magnifica, Physiol. Zool. 57, 648-662.

Bayne, B. L., Thompson, R. J., Widdows J., 1973. Some effects of temperature and food on the rate of oxygen consumption by Mytilus edulis L. In, Effects of temperature on ectothermic orqanisms. edited by W. Wieser, Springer-Verlag, Heidelberg, pp. 181-193.

Bayne, B.L., Newell, R.C., 1983. Physiological energetics of marine molluscs. In: Saleuddin, A.S.M., Wilbur, K.M. (Eds.), The Mollusca, Physiology, Part 1. Academic press, pp. 407-515 Boetius, A., Wenzhofer, F., 2013. Seafloor oxygen consumption fuelled by methane from cold seeps. Nature Geoscience 6, 725-734.

Boss, K.J., Turner, R.D., 1980. The giant white clam from the Galapagos Rift, Calyptogena magnifica species novum, Malacologia 20, 161-194.

Caprais, J.C., Lanteri, N., Crassous, P., Noel, P., Bignon, L., Rousseaux, P., Pignet, P., Khripounoff, A., 2010. A new CALMAR benthic chamber operating by submersible, First application in the cold-seep environment of Napoli mud volcano (Mediterranean Sea).

Limnol. Oceanogr. Methods 8, 304-312.

Carritt, D. E., and Carpenter J. H., 1966. Comparison and evaluation of currently employed modifications of the Winkler method for determining dissolved oxygen in sea water: A

NASCO report. J. Mar. Res. 24, 286-318. 
551 Childress, J.J., Mickel, T.J., 1982.Oxygen and sulfide consumption rates of the vent clam

552 Calyptogena pacifica, Mar. Biol. Lett. 3, 73-79.

553 Childress, J.J., Arp, A.J., Fisher, C.R. Jr., 1984 . Metabolic and blood characteristics of the 554 hydrothermal vent tube-worm Riftia pachyptila.Mar. Biol. 83, 109-124.

555 Childress, J.J. Mickel, T.J., 1985. Metabolic rates of animals from the hydrothermal vents and 556 other deep-sea habitats, Biol. Soc. Wash. Bull. 6, 249-260.

557 Cosel Von R., Olu, K., 2009. Large Vesicomyidae (Mollusca: Bivalvia) from cold seeps in 558 the Gulf of Guinea off the coasts of Gabon, Congo and northern Angola, Deep Sea Res. II 56, $559 \quad 2350-2379$.

560 Decker, C., Caprais J.-C., Khripounoff A., Olu K., 2012. First respiration estimates of cold561 seep vesicomyid bivalves from in situ total oxygen uptake measurements. C. R. Biol., 335, $562 \quad 261-270$.

563 Desbruyères, D., Biscoito, M., Caprais, J.C., Colaço, A., Comtet, T., Crassous, P., Fouquet, 564 Y., Khripounoff, A., Le Bris, N., Olu, K., Sarradin, P.M., Segonzac, M., Vangriesheim, A., 565 2001. Variations in deep-sea hydrothermal vent communities on the Mid-Atlantic Ridge when 566 approaching the Azores plateau. Deep-Sea Res. 148, 1325-1346.

567 Duperron, S., Nadalig, T., Caprais, J.-C., Sibuet, M., Fiala-Medioni, A., Amann, R., Dubilier, 568 N., 2005. Dual Symbiosis in a Bathymodiolus sp. Mussel from a Methane Seep on the Gabon 569 Continental Margin (Southeast Atlantic): 16S rRNA Phylogeny and Distribution of the 570 Symbionts in Gills. Appl. Environ. Microbiol.71, 1694-1700.

572 Fiala-Medioni, A., Le Pennec, M., 1988. Structural adaptations in the gill of the Japanese 573 subduction zone bivalves (Vesicomyidae) Calyptogena phaseoliformis and Calyptogena 574 laubieri. Oceanologica acta.11, 185-192. 
Fiala-Médioni, A., Le Pennec, M., 1989. Adaptative features of the bivalve mollusks associated with fluid venting in the subduction zones off Japan. Palaeogeogr. Palaeoclimatol. Palaeoecol. 71, 161-167.

Fiala Medioni, A, McKiness, Z. P., Dando, P, Boulegue, J, Mariotti, A, Alayse, A.-M., Robinson, J., Cavanaugh, C., 2002. Ultrastructural, biochemical, and immunological characterization of two populations of the mytilid mussel Bathymodiolus azoricus from the Mid-Atlantic Ridge: evidence for a dual symbiosis. Mar. Biol. 141, 1035-1043.

Felden, J., Wenzhöfer, F., Feseker, T., and Boetius, A., 2010. Transport and consumption of oxygen and methane in different habitats of the Hakon Mosby Mud Volcano (HMMV). Limnol. Oceanogr.55, 2366-2380.

Fisher, C.R., Childress, J.J., Arp, A.J., Brooks, J.M., Distel, D.L., Dugan, J.A. et al., 1988. Variation in the hydrothermal vent clam, Calyptogen magnifica, at the Rose Garden vent on the Galapagos spreading center. Deep Sea Res. A 35, 1811-1831.

Fischer, D., Sahling, H., Nöthen, K., Bohrmann, G., Zabel M., and Kasten, S., 2012. Interaction between hydrocarbon seepage, chemosynthetic communities, and bottom water redox at cold-seeps of the Makran accretionary prism: insights from habitat-specific pore water sampling and modeling. Biogeosciences, 9, 2013-2031, 2012.

Goffredi, S.K., Barry, J.P., 2002. Species-specific variation in sulfide physiology between closely related Vesicomyid clams. Mar. Ecol. Prog. Ser. 225, 227-238.

Hatcher, A., 1989. RQ of benthic marine invertebrates. Marine Biol. 102, 445-452.

Henry, M. S., Childress, J. J., Figueroa, D., 2008.Metabolic rates and thermal tolerances of chemoautotrophic symbioses from Lau Basin hydrothermal vents and their implications for species distributions. Deep Sea Res. 55, 679-695. 
Holmes, R.M., Aminot, A., Kerouel, R., Hooker, B.A., Peterson, B.J., 1999. A simple and precise method for measuring ammonium in marine and freshwater ecosystems. Can. J. Fish. Aquat. Sci. 56, 1801-1808.

Ikeda T., 1977. The effect of laboratory conditions on the extrapolation of experimental measurements to the ecology of marine zooplankton. IV. Changes in respiration and excretion rates of boreal zooplankton species maintained under fed and starved conditions. Mar. Biol $41,241-252$.

Ikeda T, Torres JJ, Hernandez-Leon S, Geiger SP, 2000. Metabolism. In: Harris RP, Wiebe PH, Lenz J, Skjoldal HR, Huntley M (eds) ICES zooplankton methodology manual. Academic Press, San Diego, pp 455-532.

Järnegren, J., Altin D., 2006. Filtration and respiration of the deep living bivalve Acesta excavata(J.C. Fabricius, 1779) (Bivalvia; Limidae). J. Exp. Mar. Biol. Ecol. 334, 122-129 Lutz, R.A., Kennish M.J., 1993. Ecology of deep-sea hydrothermal vent communities: a review, Rev. Geophys. 31, 211-242.

Kaltin, S., Haraldsson, C., Anderson, L.G., 2005. A rapid method for determination of total dissolved inorganic carbon in seawater with high accuracy and precision. Mar. Chem. 96, 53. Kérouel, R., Aminot, A., 1997.Fluorometric determination of ammonia in sea and estuarine waters by direct segmented flow analysis. Mar. Chem. 57, 265-275.

Khripounoff, A., Vangriesheim, A., Babonneau, N., Crassous, P., Dennielou, B., Savoye, B., 2003. Direct observation of intense turbidity current activity in the Zaire submarine valley at 4000m water depth. Mar. Geol. 194, 151-158.

Khripounoff, A., Caprais, J.C., Le Bruchec, J., Rodier, P., Noel, P., Cathalot, C., 2014. Deep cold-water coral ecosystems in the Brittany submarine canyons (Northeast Atlantic): Hydrodynamics, particle supply, respiration, and carbon cycling. Limnol. Oceanogr. 59, 8798. 
Khripounoff, A., Caprais, J.C., Decker, C., Essirard, M., Le Bruchec, J., Noel, P., Olu, K., 2015. Variability in gas and solute fluxes through deep-sea chemosynthetic ecosystems inhabited by vesicomyid bivalves in the Gulf of Guinea. Deep-Sea Res. 195, 122-130.

Krylova, E. M., Sahling H, 2010. Vesicomyidae (Bivalvia): current taxonomy and distribution. PLoS ONE 5, 1-9.

Mahaut, M.-L., Sibuet, M., Shirayama,Y., 1985.Weight-dependent respiration rates in deepsea organisms. Deep sea Res. I. 42, 1575-1582.

Marcon, Y., Sahling, H., Allais, A.G., Bohrmann, G., Olu. K., 2014. Distribution and temporal variation of mega-fauna at the Regab pockmark (Northern Congo Fan), based on a comparison of videomosaics and geographic information systems analyses. Mar. Ecol. 35, 7795.

Mayzaud, P., Conover, R.J., 1988. O:N atomic ratio as a tool to describe zooplankton metabolism. Marine ecology progress series 45, 289-302.

Navarro, J M., Gonzalez, C.M., 1998. Physiological responses of the Chilean scallop Argopecten purpuratus to decreasing salinities. Aquaculture 167, 315-327.

Newton I. L.G., Girguis P.R., Cavanaugh C.M; 2008. Comparative genomics of vesicomyid clam (Bivalvia: Mollusca) chemosynthetic symbionts. BMC Genomics. 2008; 9: 585.

Olu-Le Roy, K., Caprais, J.-C., Fifis, A., Fabri, M.-C., Galéron, J., Budzinsky, H., Le Menach, K., Khripounoff, A., Ondreas, H., Sibuet, M., 2007. Cold-seep assemblages on a giant pockmark off West Africa: spatial patterns and environmental control. Mar. Ecol. 28, $115-130$.

Pop Ristova P., Wenzhofer F., Ramette A., Zabel M., Fischer D., Kasten S., Boetius A., 2012. Bacterial diversity and biogeochemistry of different chemosynthetic habitats of the REGAB cold-seep (West African margin, 3160m water depth). Biogeosciences, 9, 5031-5048. 
647 Ritt, B., Pierre, C., Gauthier, O., Wenzhöfer, F., Boetius, A., Sarrazin, J., 2011. Diversity and 648 distribution of cold-seep fauna associated with different geological and environmental settings 649 at mud volcanoes and pockmarks of the Nile Deep-Sea Fan, Mar. Biol., 158, 1187-1210. 650 Roeselers, G., Newton, I. L. G., 2012. On the evolutionary ecology of symbioses between 651 chemosynthetic bacteria and bivalves Appl Microbiol Biotechnol 94, 1-10.

652 Sahling, H., Rickert, D., Lee, R.W., Linke, P., Suess, E., 2002. Macrofaunal community 653 structure and sulfide flux at gas hydrate deposits from the Cascadia convergent margin, NE 654 Pacific. Mar. Ecol. Prog. Ser. 231, 121-138.

655 Shumway, S.E., Newell, R.C., 1984. Energy resource allocation in Mulinia lateralis (Say), an 656 opportunistic bivalve from shallow water sediments. Ophelia 23, 101-118.

657 Sarradin, P.-M., Caprais, J.C., 1996. Analysis of dissolved gases by headspace sampling, gas 658 chromatography with columns and detectors commutation. Preliminary results. Anal. Com. $65933,371-373$.

660 Sibuet, M., Olu, K., 1998. Biogeography, biodiversity and fluid dependence of deep-sea cold661 seep communities at active and passive margins, Deep Sea Res. II 45, 517-567.

662 Schmidt-Nielsen, K., 1997. Animal physiology: adaptation and environment ( $5^{\text {th }}$ ed.).

663 Cambridge University Press, London, 570 p.

664 Smith Jr., K. L., 1985. Deep-sea hydrothermal vent mussels: nutritional state and distribution 665 at the Galapagos Rift. Ecology 66, 1067-1080.

666 Sommer, S., Pfannkuche, O., Linke, P., Luff, R., Greinert, J., Drews, M., Gubsch, S., Pieper, 667 M., Poser, M., and Viergutz, T., 2006. Efficiency of the benthic filter: Biological control of 668 the emission of dissolved methane from sediments containing shallow gas hydrates at Hydrate 669 Ridge, Global Biogeochem. Cy 20, GB2019. 
670 Sommer, S., Linke, P., Pfannkuche, O., Niemann, H., and Treude, T., 2010. Benthic

671 respiration in a seep habitat dominated by dense beds of ampharetid polychaetes at the

672 Hikurangi Margin (New Zealand ). Mar. Geol. 272, 223-232.

673 Taylor, A. C., Brand, A. R., 1975; Effects of hypoxia and body size on the oxygen

674 consumption of the bivalve Artica islandica (L.). J; exp. Mar. Biol. Ecol. 19, 187-196.

675 Tedengren, M; Andre, C; Johannesson, K; Kautsky, N., 1990. Genotypic and phenotypic

676 differences between Baltic and North Sea populations of Mytilus edulis evaluated through

677 reciprocal transplantations. 3 Physiology. Mar. Ecol. Prog. Ser.59, 221-227.

678 Vahl, O., 1973. Porosity of the grill, oygen consumption and pumping rate in Cardium edule

679 (L.). Ophelia 10, 109-118.

680 Vangriesheim, A., Khripounoff, A., Crassous, P.,2009. Turbidity events observed in situ

681 along the Congo submarine channel. Deep-Sea Res. Part II 56, 2208-2222.

682 Vetter, R.D., Powell, M.A., Somero, G.N., 1991. Metazoan adaptations to hydrogen sulphide.

683 In: Bryant C (ed) Metazoan life without oxygen. Chapman and Hall: 109-128

684 Von Bertalanffy, L., 1957. Quantitative laws in metabolism and growth. Q. Rec. Biol., 32, $685 \quad 217-231$.

686 Widdows, J., Donkin, P., Salkeld, P. N., Cleary, J. J., Lowe, D. M., Evans, S. V., Thomson, P.

687 E., 1984. Relative importance of environmental factors in determining physiological

688 differences between two populations of mussels (Mytilus edulis) Mar. Ecol. Prog. Ser. 17, 33-

68947.

690 Whiticar, M.J., 1999. Carbon and hydrogen isotope systematics of bacterial formation and

691 oxidation of methane. Chem. Geol. 161, 291-314.

692 Zaiko, A., Paskauskas, R., Krevs, A., 2010. Biogeochemical alteration of the benthic

693 environment by the zebra mussel Dreissena polymorpha (Pallas). Oceanologia 52, 649-667. 


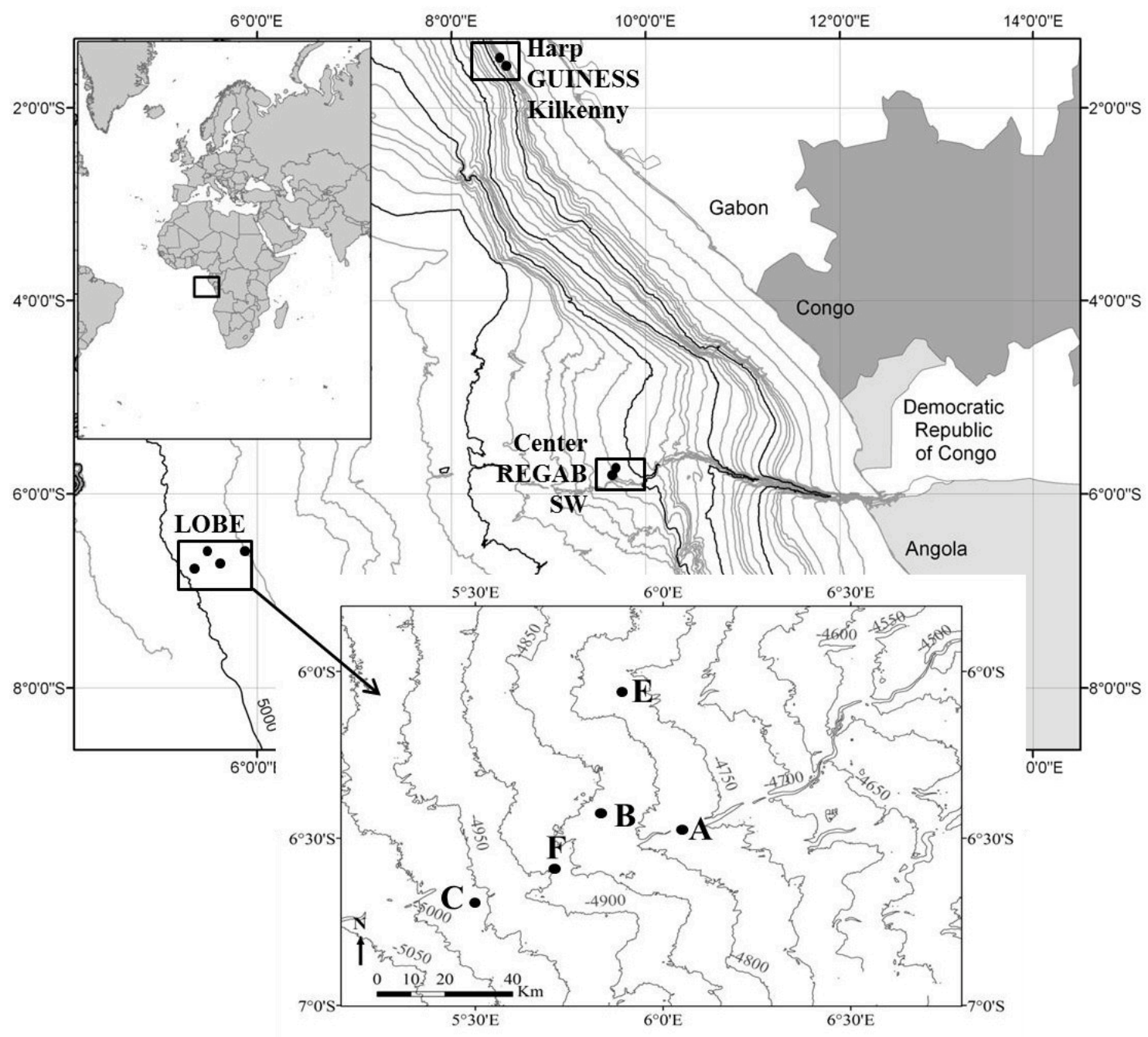

Figure 1 : Location of the study stations in the Gulf of Guinea. 

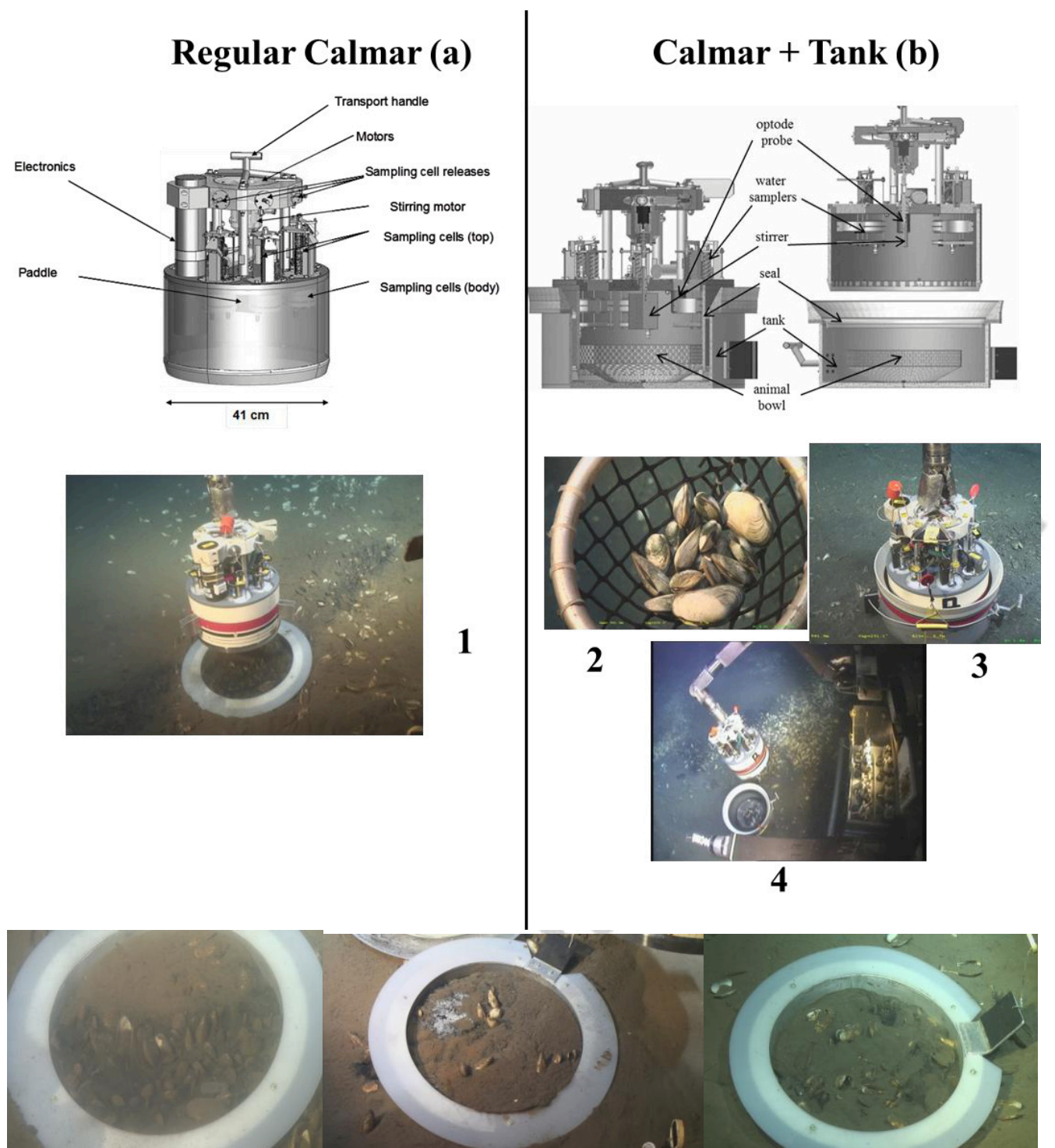

Lobe A

1

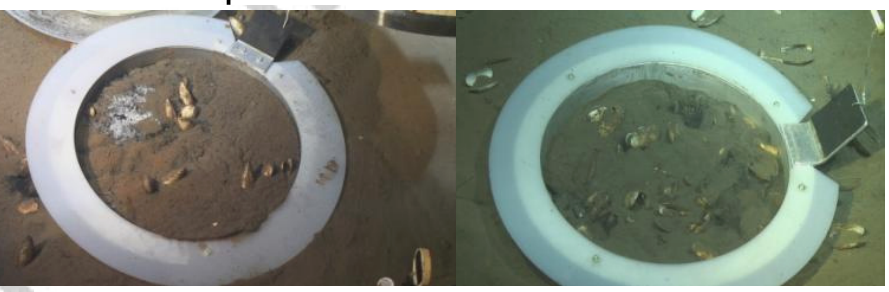

Lobe F

Lobe B

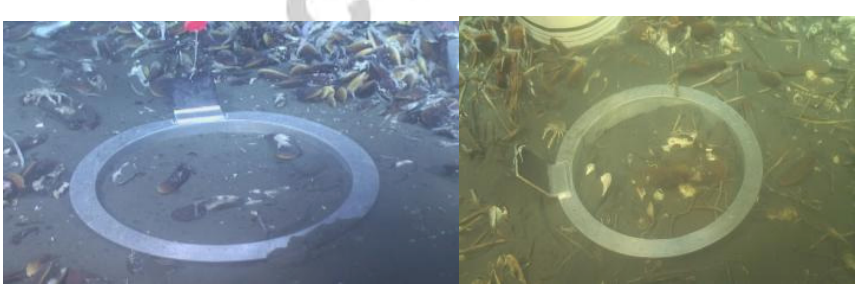

Regab Center

Regab Center

Figure 2: Top: Examples of deployment of Calmar benthic chambers during the Congolobe cruise. Pictures on the left: (a) diagram of the standard Calmar, (1) the ring delimiting the surface area measured and (1) the Calmar chamber placed on the delimited sediment.

Pictures on the right: (b) diagram of the Calmar benthic chamber fitted with a tank, (2) vesicomyids sampled with a net (3) the modified Calmar fitted with a tank and (4) general view of the experiment with use of the ROV arms.

Bottom: Illustrations of different sediments with bivalves before the deployment of the standard Calmar. 

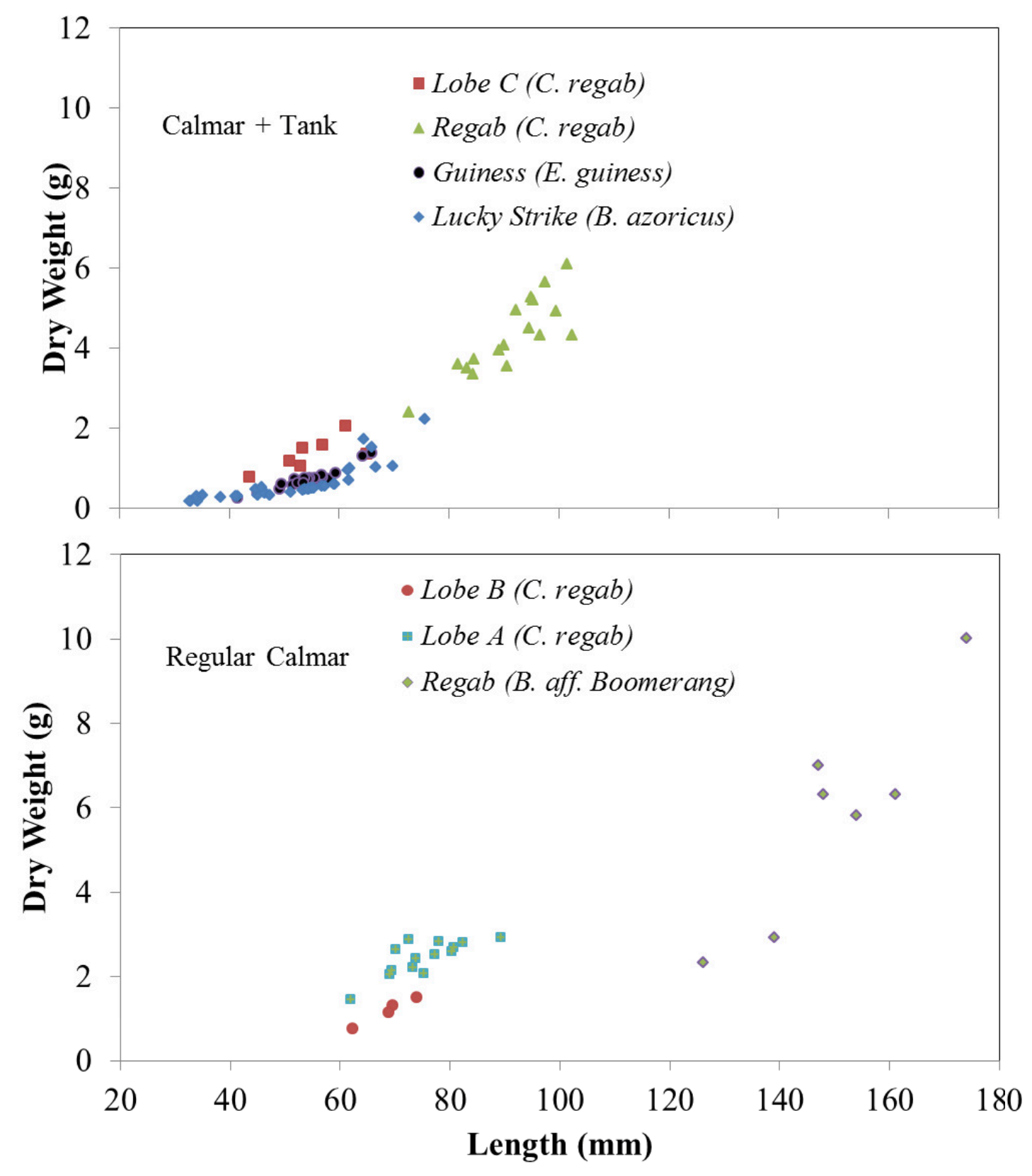

Figure 3: Characteristics of the bivalves used in the incubation experiments with the standard Calmar benthic chamber and the modified Calmar chamber fitted with a tank (The length of bivalves is the antero-posterior size). 


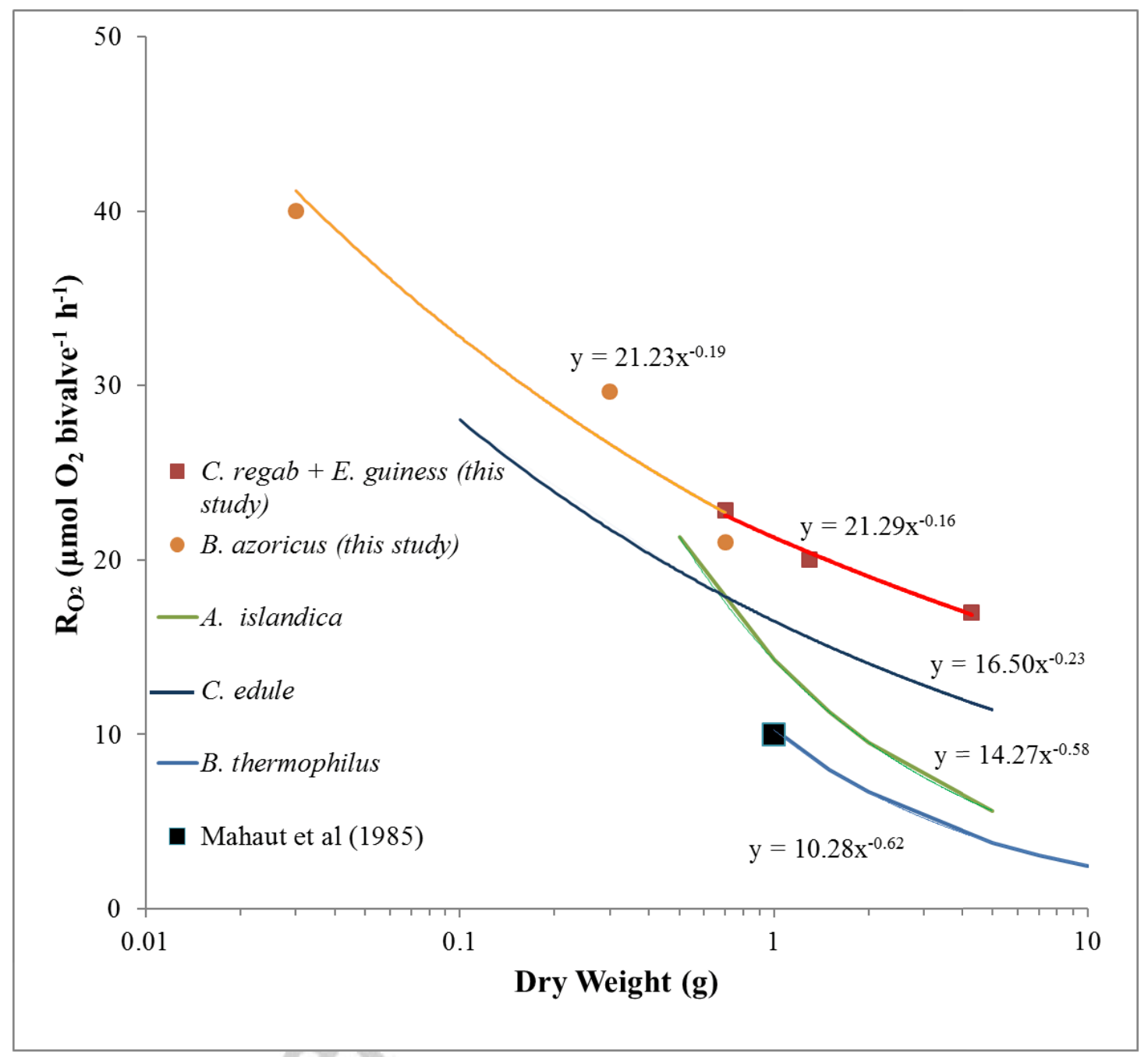

Figure 4: Relationship between individual oxygen consumption $\left(\mathrm{R}_{\mathrm{O} 2}\right)$ and dry weight for various bivalve species (This study; Bathymodiolus thermophilus, Smith Jr, 1985; Artica islandica, Taylor and Brand, 1975; Cardium edule, Vahl, 1973, Mahaut et al, 1985) 
Table 2: Biomass of bivalves calculated under the standard Calmar.

\begin{tabular}{|c|c|c|c|c|c|}
\hline $\begin{array}{l}\text { Station } \\
\text { (Marker) }\end{array}$ & $\begin{array}{c}\text { Dominant } \\
\text { species under } \\
\text { Calmar }\end{array}$ & $\begin{array}{l}\text { Density } \\
\text { by photos } \\
\left(\text { ind. } \mathrm{m}^{-2}\right) \\
\end{array}$ & $\begin{array}{l}\text { Density } \\
\text { by corer } \\
\left(\text { ind. } \mathrm{m}^{-2}\right) \\
\end{array}$ & $\begin{array}{c}\text { Mean } \\
\text { density } \\
\left(\text { ind. } \mathrm{m}^{-2} \text { ) }\right. \\
\end{array}$ & $\begin{array}{c}\text { Biomass } \\
\left(\mathrm{g} \text { dry weight } \mathrm{m}^{-2}\right)\end{array}$ \\
\hline $\begin{array}{c}\text { Regab } \\
\text { (W06/M3) }\end{array}$ & $\begin{array}{l}\text { Bathymodiolus. } \\
\text { aff. boomerang }\end{array}$ & 15 & & 15 & 75 \\
\hline $\begin{array}{c}\text { Regab } \\
\text { (W02/M2) }\end{array}$ & $\begin{array}{c}B . \text { aff. } \\
\text { boomerang }\end{array}$ & 18 & & 18 & 90 \\
\hline $\begin{array}{l}\text { Lobe A } \\
(\text { CoL- } 01)\end{array}$ & $\begin{array}{c}\text { Christineconcha } \\
\text { regab }\end{array}$ & 185 & 485 & 335 & 1066 \\
\hline $\begin{array}{c}\text { Lobe F } \\
(\text { CoL-03) }\end{array}$ & $\begin{array}{l}\text { Calyptogena } \\
\text { southwardae }\end{array}$ & 50 & 114 & 82 & 329 \\
\hline $\begin{array}{c}\text { Lobe B } \\
(\text { Col-11) }\end{array}$ & C. regab & 71 & 143 & 107 & 157 \\
\hline
\end{tabular}


Table 3: Elementary composition of bivalve tissues (\% total $\mathrm{C}$ and $\mathrm{S}) .($ Christineconcha regab $=$ C. regab, Elenaconcha guiness $=$ E. guiness,

Bathymodiolus aff. Boomerang= B. aff. Boomerang, Bathymodiolus azoricus= B.azoricus)

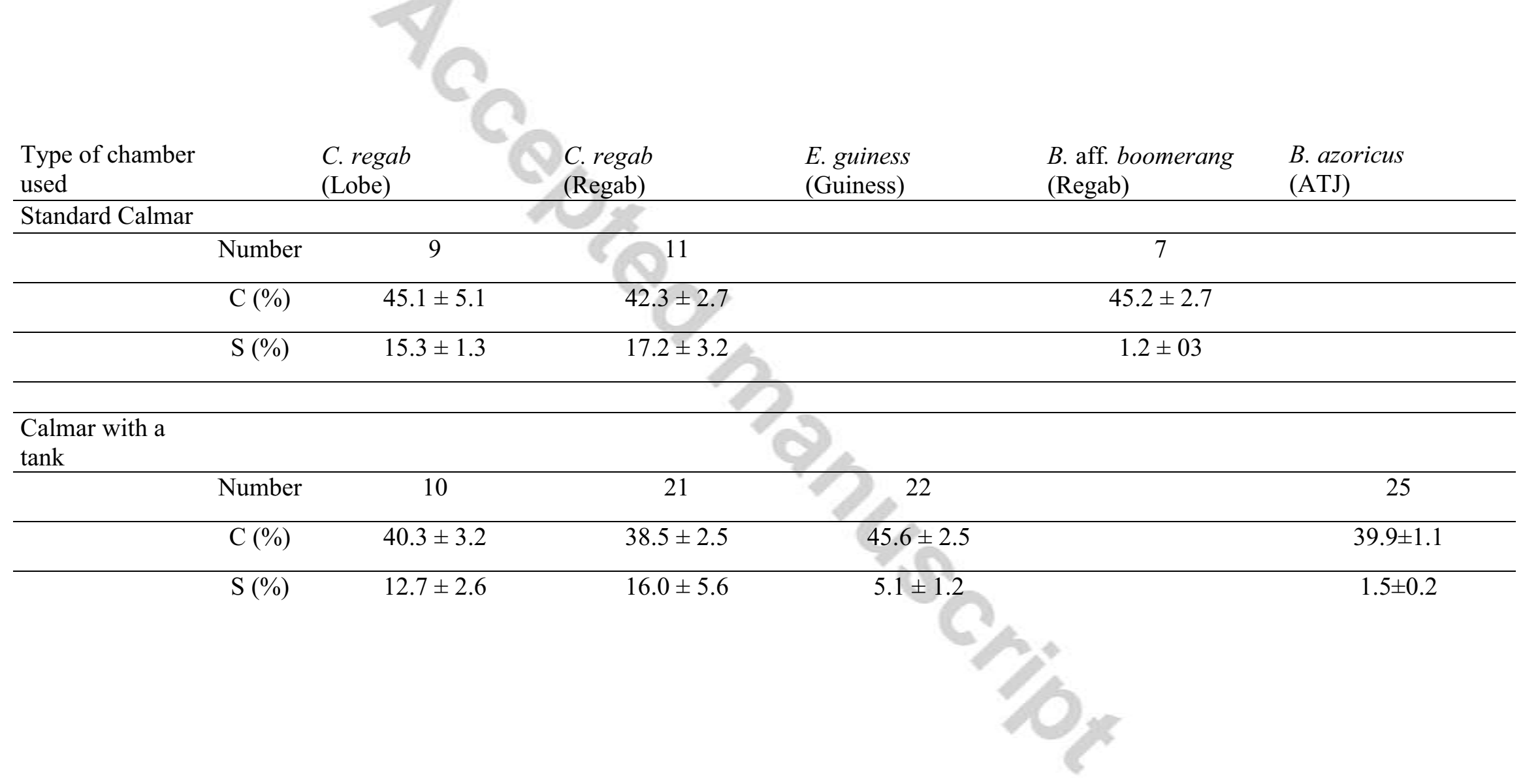


Table 4: Flux of $\mathrm{O}_{2}, \Sigma \mathrm{CO}_{2}, \mathrm{NH}_{4}{ }^{+}$and $\mathrm{CH}_{4}$ measured under the standard Calmar in this study and similar values found in the literature.

(Christineconcha regab = C. regab, Calyptogena valdiviae $=$ C. valdiviae, Bathymodiolus aff. Boomerang= B. aff. Boomerang, Abyssogena

southwardae $=$ A. southwardae)

\begin{tabular}{|c|c|c|c|c|c|c|c|}
\hline Station & $\begin{array}{l}\text { Dominant } \\
\text { Species }\end{array}$ & $\begin{array}{c}\mathrm{O}_{2} \\
\left(\mathrm{mmol} \mathrm{m}{ }^{-2} \mathrm{~h}^{-1}\right)\end{array}$ & $\begin{array}{c}\Sigma \mathrm{CO}_{2} \\
\left(\mathrm{mmol} \mathrm{m}^{-2} \mathrm{~h}^{-1}\right)\end{array}$ & RQ & $\begin{array}{c}\mathrm{NH}_{4}^{+} \\
\left(\mathrm{mmol} \mathrm{m}^{-2} \mathrm{~h}^{-1}\right)\end{array}$ & $\begin{array}{c}\mathrm{CH}_{4} \\
\left(\mathrm{mmol} \mathrm{m}^{-2} \mathrm{~h}^{-1}\right)\end{array}$ & \\
\hline Regab Center & B. aff. boomerang & -1.29 & 1.04 & 0.03 & 0.10 & 1.80 & \multirow{7}{*}{ This study } \\
\hline Regab Center & B. aff. boomerang & -1.42 & & & & & \\
\hline Lobe A & C. regab & -6.71 & 9.58 & 0.06 & 0.24 & 4.52 & \\
\hline Lobe A & Reference & 0.3 & 6 & & 0.01 & & \\
\hline Lobe F & A. southwardae & -2.04 & 3.08 & 0.06 & 0.16 & 0.54 & \\
\hline Lobe $\mathrm{C}$ & Reference & 0.4 & 0.45 & 1.1 & 0.03 & 0.1 & \\
\hline Lobe B & C. regab & -1.79 & 3.13 & 0.07 & 0.16 & 0.35 & \\
\hline Regab SW & C. regab & -11.33 & 2.08 & 0.01 & 0.37 & 0.51 & \multirow{6}{*}{$\begin{array}{l}\text { Khripounoff et al. } \\
\qquad(2015)\end{array}$} \\
\hline Regab Center & C. regab & -18.04 & 3.58 & 0.01 & 0.43 & 1.91 & \\
\hline Guiness Kilkenny & C. valdiviae & -1.17 & 3.96 & 0.14 & & & \\
\hline Guiness Harp & C. valdiviae & -11.29 & 6.46 & 0.03 & & & \\
\hline Lobe A & C. regab & -6.54 & 1.50 & 0.01 & 0.31 & 0.08 & \\
\hline Lobe $\mathrm{C}$ & C. regab & -14.42 & 77.38 & 0.23 & 2.99 & 5.79 & \\
\hline Regab Center & C. regab & -13.83 & & & 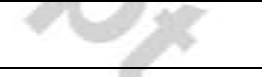 & 0.61 & \multirow{2}{*}{ Decker et al. (2012) } \\
\hline Regab SW & C. regab & -20.50 & & & 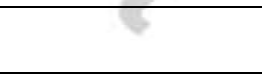 & 0.01 & \\
\hline Regab Center & C. regab & -12.96 & & & & $0.04-3.38$ & $\begin{array}{l}\text { Pop Ristova et al. } \\
\text { (2012) }\end{array}$ \\
\hline
\end{tabular}


Table 1: Characteristics and origins of vesicomyids and mytilids used in this study (Equipment: $\mathrm{C}=$ standard Calmar and $\mathrm{CT}=$ Calmar with a tank)

\begin{tabular}{|c|c|c|c|c|c|}
\hline $\begin{array}{l}\text { Station (Cruise- } \\
\text { Marker) }\end{array}$ & Position & Species & $\begin{array}{l}\text { Depth } \\
(\mathrm{m})\end{array}$ & $\begin{array}{c}\text { Temperature } \\
\left({ }^{\circ} \mathrm{C}\right)\end{array}$ & $\begin{array}{c}\text { Dive number } \\
\text { (equipment) }\end{array}$ \\
\hline Regab (Wacs 06/M3) & $\begin{array}{l}\text { S } 5^{\circ} 47.865 \\
\text { E } 9^{\circ} 42.691\end{array}$ & $\begin{array}{l}\text { Bathymodiolus } \\
\text { aff. boomerang }\end{array}$ & 3155 & 2.55 & pl $428(\mathrm{C})$ \\
\hline Regab (Wacs 02/M2) & $\begin{array}{l}\text { S 5 } 5^{\circ} 47.869 \\
\text { E } 9^{\circ} 42.689\end{array}$ & $\begin{array}{l}\text { B. aff. } \\
\text { boomerang }\end{array}$ & 3154 & 2.55 & pl $429(\mathrm{C})$ \\
\hline $\begin{array}{l}\text { Regab (Wacs } \\
\text { 03/Marker7) }\end{array}$ & $\begin{array}{l}\mathrm{S} 5^{\circ} 47.867 \\
\mathrm{E} 9^{\circ} 42.687 \\
\end{array}$ & $\begin{array}{l}\text { Christineconcha } \\
\text { regab }\end{array}$ & 3072 & 2.55 & pl $481(\mathrm{CT})$ \\
\hline $\begin{array}{l}\text { Guiness Harp } \\
\text { (Congolobe) }\end{array}$ & S 134.647 & $\begin{array}{l}\text { Elenaconcha } \\
\text { guiness / } \\
\text { Calyptogena } \\
\text { valdiviae } \\
\end{array}$ & 582 & & pl 495 (CT) \\
\hline $\begin{array}{l}\text { Lobe A (Congolobe- } \\
01 \text { ) }\end{array}$ & $\begin{array}{l}\mathrm{S} 6^{\circ} 28.281 \\
\mathrm{E} 6^{\circ} 02.143\end{array}$ & C. regab & 4751 & 2.4 & pl $483(\mathrm{C})$ \\
\hline $\begin{array}{l}\text { Lobe F (Congolobe- } \\
\text { 03) }\end{array}$ & $\begin{array}{l}\text { S } 6^{\circ} 35.426 \\
\text { E } 5^{\circ} 41.406\end{array}$ & $\begin{array}{l}\text { Abyssogena } \\
\text { southwardae / } \\
\text { C. regab }\end{array}$ & 4873 & 2.4 & pl $486(\mathrm{C})$ \\
\hline $\begin{array}{l}\text { Lobe C (Congolobe- } \\
09 \text { ) }\end{array}$ & $\begin{array}{l}\text { S } 6^{\circ} 42.068 \\
\text { E } 5^{\circ} 29.273\end{array}$ & C. regab & 5070 & 2.4 & pl 491 (CT) \\
\hline $\begin{array}{l}\text { Lobe B (Congolobe- } \\
\text { 11) }\end{array}$ & $\begin{array}{l}\text { S } 6^{\circ} 25.229 \\
\text { E } 5^{\circ} 49.709\end{array}$ & $\begin{array}{l}\text { C. regab / A. } \\
\text { southwardae }\end{array}$ & 4712 & 2.4 & pl $492(\mathrm{C})$ \\
\hline $\begin{array}{l}\text { Lucky Strike } \\
\text { (Momarsat 2015) }\end{array}$ & $\begin{array}{l}\text { N } 7^{\circ} 17^{\prime} 336 \\
\text { W } 32^{\circ} 16.53\end{array}$ & $\begin{array}{l}\text { Bathymodiolus } \\
\text { azoricus }\end{array}$ & 1680 & 4.6 & $\begin{array}{l}\text { pl 599, 601, } \\
605(\mathrm{CT})\end{array}$ \\
\hline
\end{tabular}


Table 5: Calculated rate of $\mathrm{O}_{2}, \Sigma \mathrm{CO}_{2}, \mathrm{NH}_{4}{ }^{+}$consumed or produced by vesicomyids and mytilids using the standard Calmar chamber and the modified Calmar fitted with a tank (The dry weight of mytilids was measured without the commensal polychaeta). (Christineconcha regab=C. regab, Elenaconcha guiness =E. guiness, Bathymodiolus aff. boomerang=B. aff. boomerang, Abyssogena southwardae $=$ A. southwardae Bathymodiolus azoricus = B.azoricus, Branchipolynoe seepensis $=$ B. seepensis)

\begin{tabular}{|c|c|c|c|c|c|c|c|c|c|c|c|c|c|c|}
\hline & \multirow{2}{*}{\multicolumn{3}{|c|}{ Calmar with a tank }} & \multicolumn{7}{|c|}{ Cold system } & \multicolumn{4}{|c|}{ Hydrothermal system } \\
\hline & & & & $(\mathrm{C})$ & & Sta & ndard Calma & & & & \multicolumn{4}{|c|}{ Calmar with a tank } \\
\hline & $\begin{array}{l}\text { Regab } \\
\text { Center }\end{array}$ & $\begin{array}{l}\text { Lobe } \\
\text { C }\end{array}$ & $\begin{array}{l}\text { Guiness } \\
\text { Harp }\end{array}$ & $\begin{array}{l}\text { Regab } \\
\text { Center }\end{array}$ & $\begin{array}{l}\text { Regab } \\
\text { Center }\end{array}$ & $\begin{array}{l}\text { Regab } \\
\text { Center }\end{array}$ & $\begin{array}{l}\text { Lobe } \\
\text { C }\end{array}$ & $\begin{array}{l}\text { Lobe } \\
\text { A }\end{array}$ & $\begin{array}{l}\text { Lobe } \\
\mathrm{F}\end{array}$ & $\begin{array}{l}\text { Lobe } \\
\text { B }\end{array}$ & \multicolumn{3}{|c|}{ Lucky Strike } & $D$ \\
\hline Dominant species & $\begin{array}{l}\text { C. } \\
\text { regab }\end{array}$ & $\begin{array}{l}\text { C. } \\
\text { regab }\end{array}$ & $\begin{array}{l}\text { E. } \\
\text { guiness }\end{array}$ & $\begin{array}{l}\text { B. aff. } \\
\text { boomer- } \\
\text { ang }\end{array}$ & $\begin{array}{l}\text { B. aff. } \\
\text { boomer- } \\
\text { ang }\end{array}$ & $\begin{array}{l}\text { C. regab } \\
\text { (Khripounoff } \\
\text { et al. 2015) }\end{array}$ & $\begin{array}{l}\text { C. regab } \\
\text { (Khripounoff } \\
\text { et al. 2015) } \\
\end{array}$ & C. regab & $\begin{array}{l}\text { A. } \\
\text { south- } \\
\text { wardae } \\
\end{array}$ & C. regab & B. $a z c$ & $+B . \mathrm{sec}$ & & $\frac{2}{11}$ \\
\hline $\begin{array}{l}\text { Total dry weight } \\
\text { per Calmar }(\mathrm{g})\end{array}$ & 64.7 & 8.1 & 12.9 & 12.9 & 12.6 & & & 138.6 & 42.8 & 16.5 & 8.7 & 14.7 & 6.0 & III \\
\hline $\begin{array}{l}\text { Number of } \\
\text { bivalves }\end{array}$ & 17 & 7 & 21 & 4 & 5 & & & 6 & 8 & 8 & 22 & 19 & 170 & 3 \\
\hline $\begin{array}{l}\text { Mean individual } \\
\text { dry weight }(\mathrm{g})\end{array}$ & $\begin{array}{l}4.3 \\
\pm 1.1\end{array}$ & $\begin{array}{l}1.3 \\
\pm 0.4\end{array}$ & $\begin{array}{l}0.7 \\
\pm 0.3\end{array}$ & $\begin{array}{l}4.3 \\
\pm 1.3 \\
\end{array}$ & $\begin{array}{l}6.3 \\
\pm 0.9\end{array}$ & & & $\begin{array}{l}2.4 \\
\pm 0.9\end{array}$ & $\begin{array}{l}4.0 \\
\pm 0.5\end{array}$ & $\begin{array}{l}0.8 \\
\pm 0.2\end{array}$ & $\begin{array}{l}0.3 \\
\pm 0.1\end{array}$ & $\begin{array}{l}0.7 \\
\pm 0.2\end{array}$ & $\begin{array}{l}0.03 \\
\pm 0.01\end{array}$ & 2 \\
\hline $\begin{array}{l}\mathrm{O}_{2} \text { rate } \\
\left(\mu \mathrm{mol} \mathrm{g} \mathrm{dw} \mathrm{h}^{-1}\right)\end{array}$ & 16.1 & 17.7 & 25.7 & 16.1 & 15.8 & 10.4 & 22.9 & 6.2 & 6.3 & 11.2 & 23.3 & 19.6 & 33.6 & $\frac{0}{9}$ \\
\hline $\begin{array}{l}\Sigma \mathrm{CO}_{2} \text { rate } \\
\left(\mu \mathrm{mol} \mathrm{g}^{-1} \mathrm{dw} \mathrm{h}^{-1}\right)\end{array}$ & 16.2 & 22.9 & 28.3 & 12.7 & & 2.0 & 123 & 9.2 & 9.6 & 12.9 & 30.0 & 25.9 & 58.6 & $\bar{v}$ \\
\hline RQ & 1.0 & 1.3 & 1.1 & 0.8 & & 0.2 & 5.3 & 1.5 & 1.5 & 1.2 & 1.3 & 1.3 & 1.7 & \\
\hline $\begin{array}{l}\mathrm{NH}_{4}^{+} \text {rate } \\
\left(\mu \mathrm{mol} \mathrm{g} \mathrm{dw} \mathrm{h}^{-1}\right)\end{array}$ & 0.87 & 1.25 & & 0.83 & & 0.24 & 4.8 & 0.25 & 0.51 & 0.67 & & 0.33 & 0.53 & \\
\hline $\mathrm{O}: \mathrm{N}$ ratio & 7.4 & 5.7 & & 5.0 & & 17.3 & 2.0 & 10.6 & 4.9 & 6.7 & & 23.7 & 25.4 & \\
\hline
\end{tabular}

